\title{
各種皮弁による口腔・頻・顔面欠損の再建と臨床経過に関する検討
}

工藤㤵吾・柘植信夫・山口一成・横田光正

宮澤政義・金沢治樹・入江雅之・瀬川 清

藤岡幸雄・佐々木 純*・中里滋樹**

\section{Reconstructive surgery and clinical course using various flaps for oromaxillofacial defects}

\author{
Keigo Kudo - Nobuo Tsuge - Kazushige Yamaguchi \\ Mitsumasa Yokota - Masayoshi Mryasawa - Haruki Kanazawa \\ Masayuki IrIe - Kiyoshi Segawa - Yukio Fujroka \\ Junn SASAKI* - Shigeki NAKASATO**
}

\begin{abstract}
Reconstruction using various pedicled flaps for oromaxillofacial defects makes a patient's return to social life easier and contributes to the improvement in therapeutic results especially in malignant tumors. In the past 6 years from 1978 to 1984, a review of 35 patients where these flaps were used is as follows:

1) Deltopectoral flaps with or without the transplanted bone for secondary reconstraction of 10 cheeks and 2 mandibular defects required long terms because of the delay transferring the baps, but there was less operative invasion.

2) Major pectoralis myocutaneous flaps for 14 immediate reconstructions of the tongue, floor of mouth, oropharynx and mandible were effective in the repair of soft tissue defect, but not always successful in reconstruction using osteomyocutaneous flaps with the rib or sternum for mandibular defects.

3) In the 2 adult males, the scalp-forehead flaps for immediate reconstruction of the entire upper lip were cosmetically used to make a mustache using the hair-bearing scalp.

4) Flaps of 2 sternocleidomastoids and 5 cervical island skins for immediate reconstruction of the moderate defect in the tongue, floor of mouth and alveolus were taken at the time of neck dissection. However, some flaps caused a postoperative necrosis because of excessive tention due to suturing of the wound and insufficient blood supply, different in previous other flaps.
\end{abstract}

Reconstruction using the above-mentioned flaps was indicated in large and moderate defects. Survival rate of patients with tumor resection from one to five years was as follows; $81.1 \%$ in 11 deltopectoral flaps, $57.1 \%$ in 14 pectoralis major myocutaneous flaps and $100 \%$ in 9 other flaps.

岩手医科大学菻学部口腔外科学第 1 满座

（主任：藤岡幸雄教授）

*岩手医科大学檤学部外科

（主任：佐々木 純教授）

**岩手県立中央病院粎科口腔外科

（主任：中里滋樹科長）

Department of Oral and Maxillofacial Surgery

I, School of Dentistry, Iwate Medical Univer- sity (Chief: Prof. Yukio Fujioka)

* Division of General Surgery, School of Dentistry, Iwate Medical University (Chief: Prof. Junn Sasaki)

** Department of Dentistry and Oral Surgery, Iwate Prefectural Central Hospital (Chief: Dr. Shigeki Nakasato)

受付日：昭和60年 4 月 8 日 
Key words: regional flap, reconstruction, oromaxillofacial defect

緒

言

各種筋皮并の進歩は，口腔領域に的ける種々の欠損部 の再建を容易にし，かつ口腔の悪性腫浧の治療成績の向 上にる大きく貢献している。 われわれは最近の 6 か年間 K, 口腔・顎・顔面の比較的大きい欠損に対して，D-P

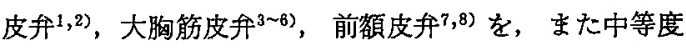
の欠損に対して 胸鎖乳突筋皮茾, ${ }^{9,10}$ および頸部島状皮

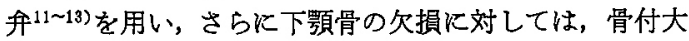
胸筋皮升 ${ }^{14 \sim 18)}$ 扎よび移植骨付 D-P 皮弁 ${ }^{19)}$ を用いて，そ れぞれ即時的あるいは二次的俩建を行ってきた。

そこで，これら筋皮并または筋骨皮并によって再建を
行った35例の，再建時に批りる注意点と臨床経過につい て検討し，さらに各種皮弁の適応について考察を加えた 結果，いささかの知見が得られたので報告する.

$$
\text { 対象 }
$$

1978年から1984年までの 6 年間に，口腔・顎・顔面欠 損の修復，再建に使用した皮并は35例であった。これら は男性26例，女性 9 例で，また年龄は25歳から80藏にわ たり，とくに50〜70藏代が大部分を占めていた，なお， 疾患と部位は，表 1 のごとくであった。 これらの欠損 は，進展または再発による悪性腫場の切除後のるのが34 例で最も多く，病理組織学的には扁平上皮癌25例, 腺系

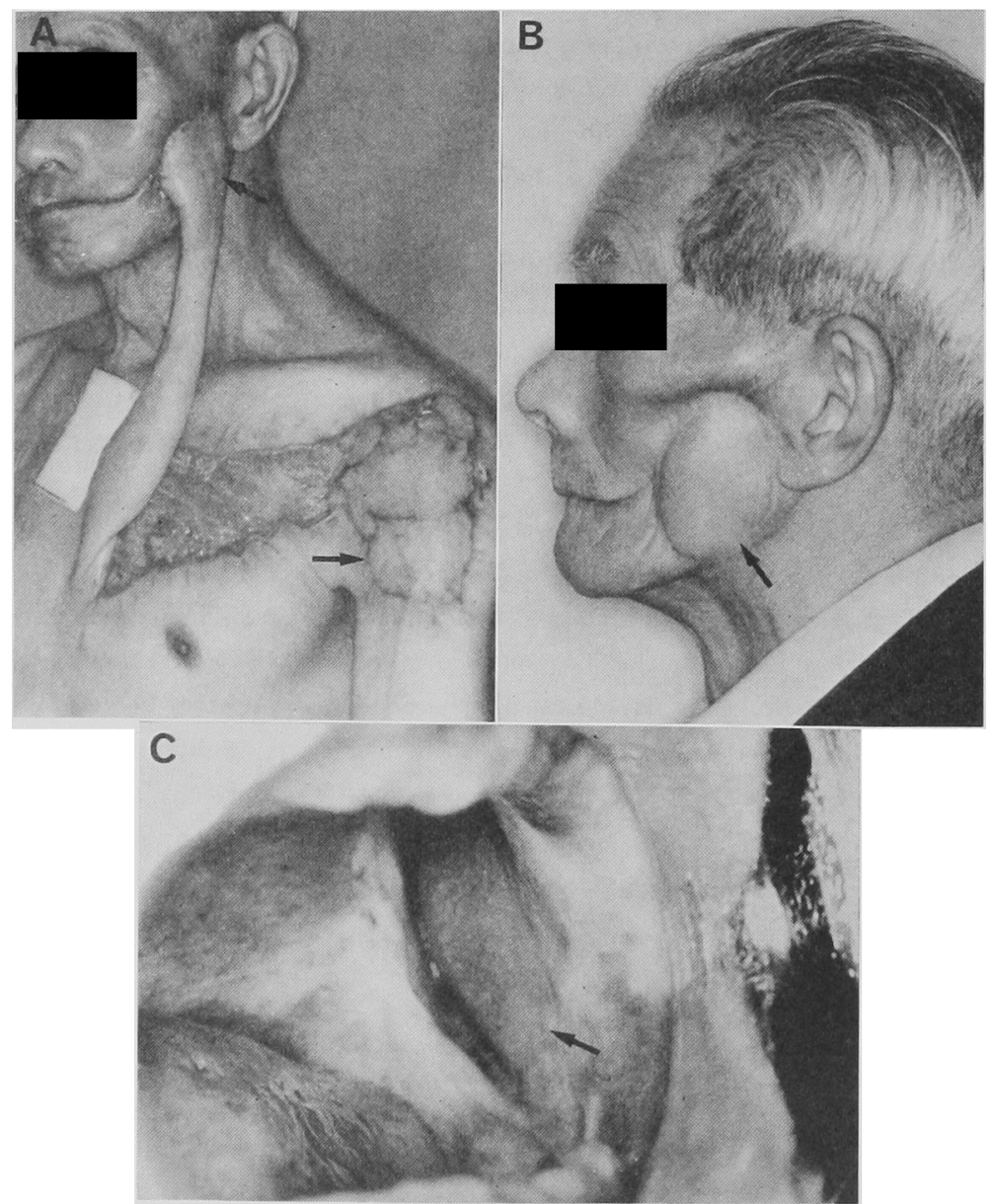

写真 1 煩粘膜癌のため，顂部全層切除後にD-P 皮升で再建した（A）の下方 矢印は，上腕部の口腔側亳打ちに使用した植皮部で，上方矢印は皮庙㑡 を示す。（B）恃再建後 2 年目の㑡貌で，（C）恃同時期の口腔内皮弁を 示す。 
表 1 疾患と部位

1. 悪性腫湯…............................29例

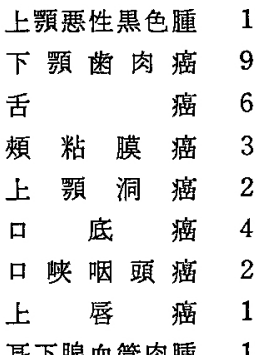

耳下腺血管肉腫 1

2. 放射線性組䋐壊死

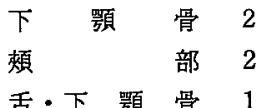

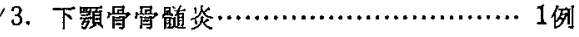

計

35 例

表 2 皮弁の種類

1. D-P 皮弁 12例

移植腸骨付・肋骨付 2

2. 大胸筋皮弁 14例

胁骨付・眴骨付 5

3. 前額皮升 2例

4. 䀢鋇爫笑筋皮弁

2 例

5. 形部島状皮弁 5 例

計

35 例

癌 2 例, 基底細胞癌 1 例, 悪性黑色腫 1 例, 血管肉尰 1 例で，また扁平上皮癌の治療後の放射線性組織壊死か゚ 5 例，慢性下顎骨骨䯣炎が 1 例であった。

皮升は欠損の範因，部位，あるいは再建時期なとによ って，表 2 のごとく分類した．な特，悪性腫湯の切除例 は, いずれも衍前に化学療法と放射線治療がなされてお り，とくに扁平上皮癌に対しては，Pepleomycin が投与 されていた。

\section{再建と臨床経過}

\section{D-P 皮弁}

全例とむ董隍切除後に，一定期間を経過してから二次 的に再建を行った，頓部就よ゙オナガイ部の全層欠損の 9 例では，口腔側の裏打らに種々の工夫を加点る必要が

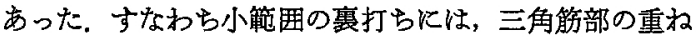
合せが容易であったが，それが比較的広範囲の場合に は，三角筋部の上腕下方への延長 ${ }^{20)}$ ，あるいは最初に口

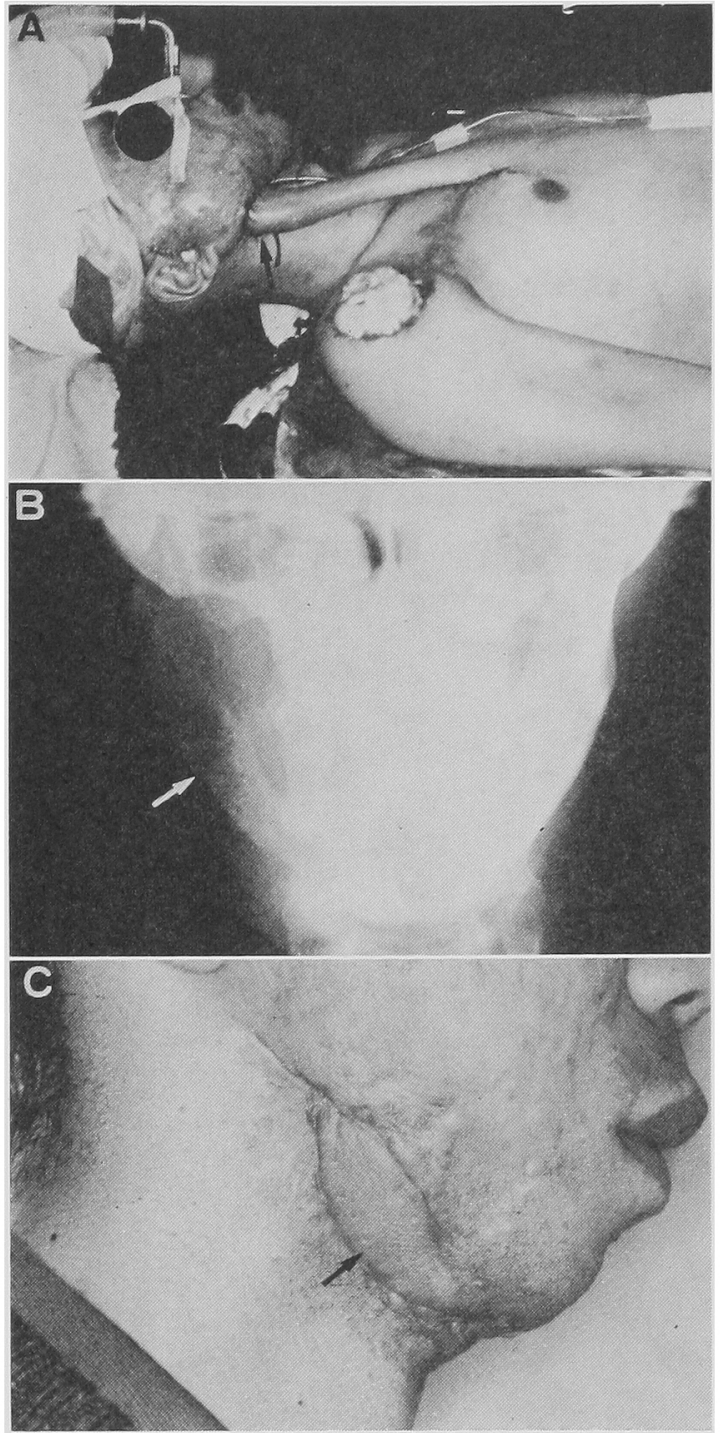

写真 2 僈性骨䯣炎による下颚骨久損部の再建例 で，筒状 D-P 皮升形成時に腸学片を移植 した、1 加月後に deepithelization し，骨 皮升として久損部へ移動した（A）。原後 感染のため一部に移植骨の吸収をみたが生 着した（B），顔面は痤㿉による政痕が著 明であるため，移植骨に皮弁の一部を付し た。

腔側を形成してから，二次的に pedicle flap を折り返し

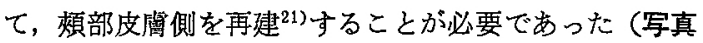
1).

下顓骨辺緣部の放射線性骨壊死に対しては, 即時的再 建が容易であった。しかし下顎骨の離断例では，あらか しめ腸骨または肋骨を皮弁内に移植し，その後に骨付筒 


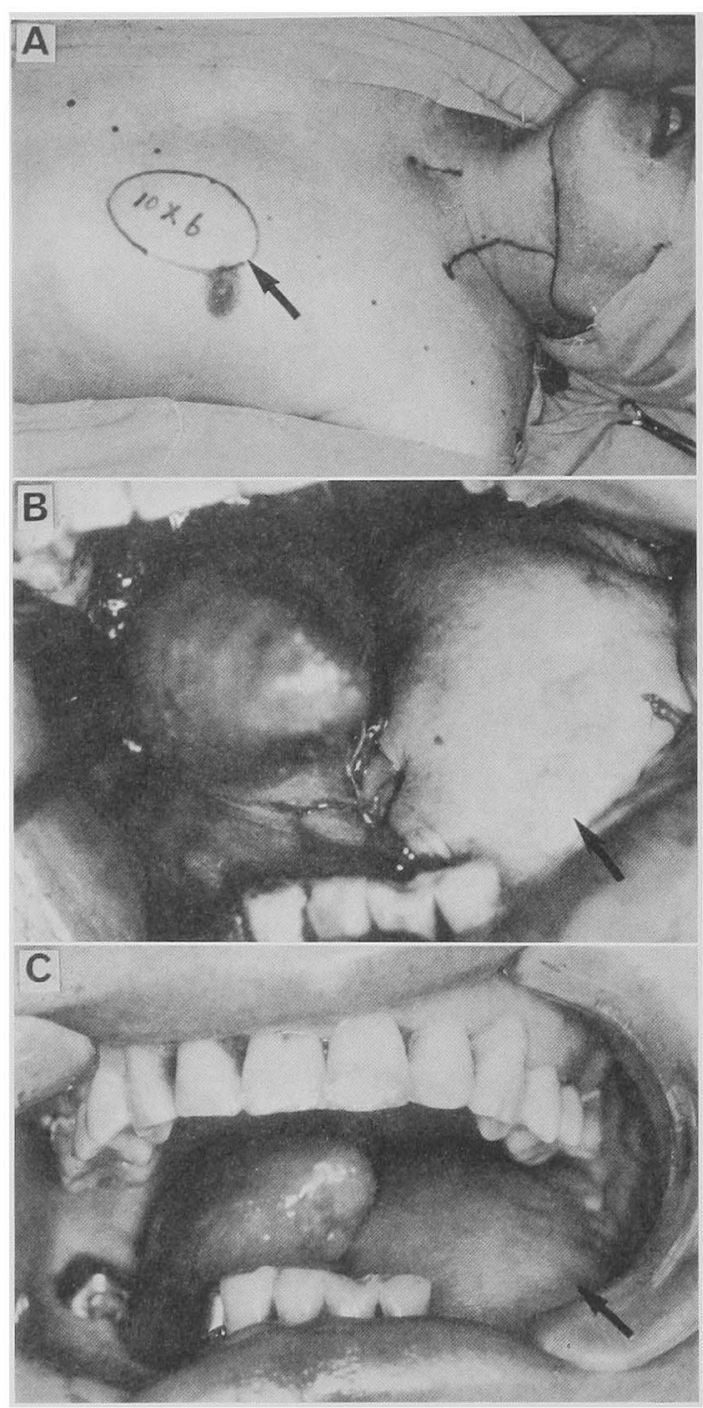

写真 3 再発舌率の亜全摘例で, 頸部郭清に先立っ て大跑能皮升をデザイン（A）し，即特再 建を行った（B）. 残存舌尖部老皮弁に繾 合しないようにすると，舌の運動性が保存 でき，発語も比较的明膫である（C).

状皮弁として下額骨再建に使用した（写真 2). 皮弁か ら移植骨への血行は，1 か月の経過によって良好となる が，移動後の下買部に扣いては感染をきたしやすかっ た．腸骨付皮弁による下顎骨再建の１例は，経過が良好 であったが，胁骨付皮弁の１例は，固定に使用した mini plate のネジがゆるんたために，偽関節を後遺して経過 は不良であった。

皮升の壊死は 1 例る経験しなかったが，数次にわたる delay と皮弁の移動のために，長期間を要する欠点があ った.
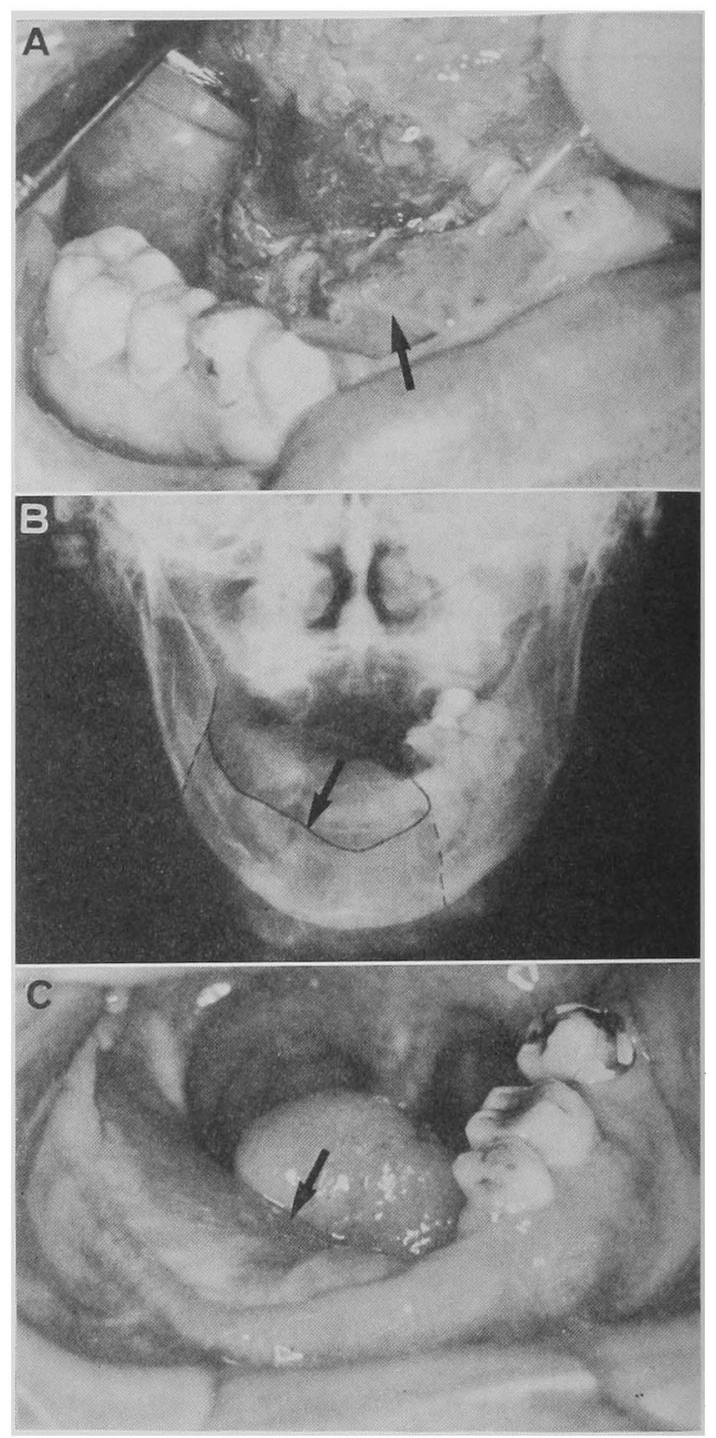

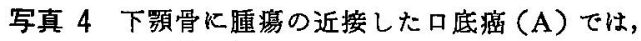
下䫇骨舌側の辺緑切除によって下顎骨の連 続性を保存し（B），さらK舌の科的前方 半分を切除して，この部を大胸筋皮弁で再

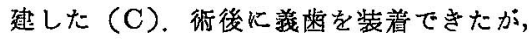
発語および㷛下は比校的強く障害された。

\section{2. 大胸筋皮弁}

舌, 口底, 中咽頭, 下䫑なとの欠損の14例に即時再建 を行った。大胸能皮弁は钼部の郭清創のみならず，口腔 の大きい欠損の補媜に対しても mass augmentation が 得られるので, きわめて有用であった，乙かし再建した 舌は運動性に之しかったため, 燕下および会話について は，舌尖部の一部が保存された例では比校的良好であっ た（写真 3). 一力，舌尖部を切除した症例では機能の 

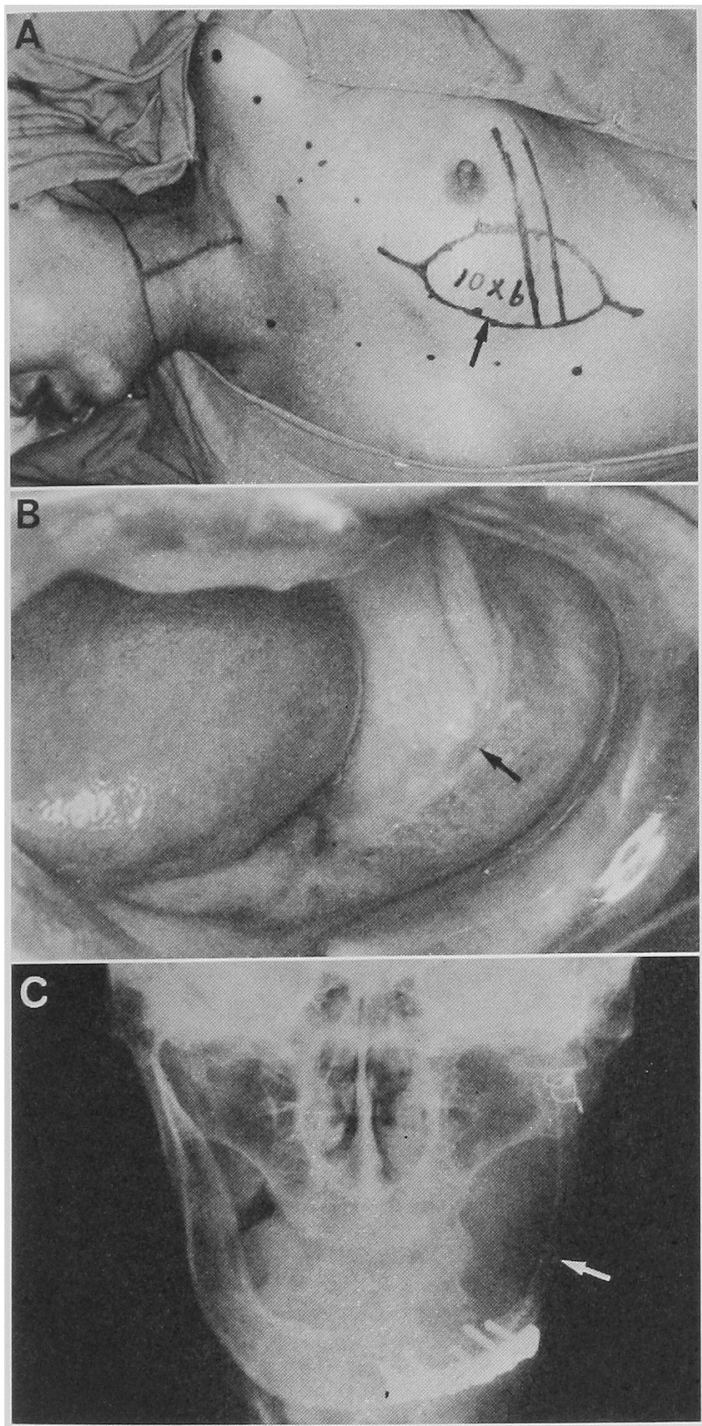

写真 5 下顎の粘表皮腫のため下顎区域切除後に， 第 5 助骨付大胸觔皮弁 (A) で再建した。 皮弁は 6 か月後に注庄坦となり（B）， 義萪も装着できた。助軟骨部は A-O plate で, 関節突起部は wire で, それだれ固定 した（C).

回復が困難であった（写真 4$).$

腫湯が下顎骨の内側に近接していた 3 例では，下䋶骨 の舌側を切除して下澦骨の連続性を保存しここの部を筋 皮弁で修復した（写真 4 ）、第 5 肋骨付大胸筋皮弁によ る下顎骨の再建例は，4 例中の 2 例が 良好飞経過した (写真 5)。しかし感染のため，1 例は肋軟骨部を，他の 1 例㤬全移植骨を摘出した，肋骨への血行が，助軟骨膜 とそれに接する前方部の肋骨骨膜のみに依存しているた
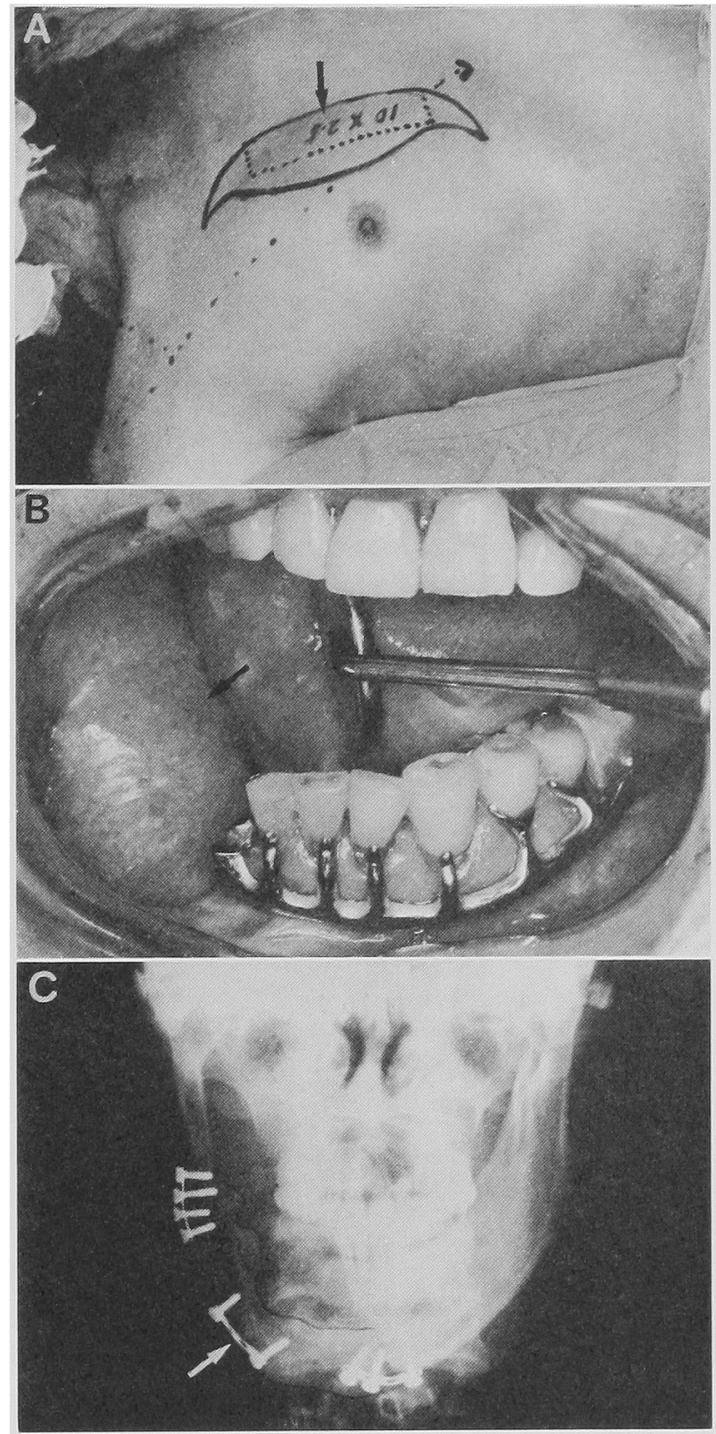

写真 6 下顎の再発菌肉癌切除後の連絩欠損部を全 層胸骨付大胸筋皮弁 (A) で再建した。皮

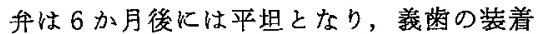
が可能となった（B）。再建時飞下顎角相 当の胸骨は，矢印部で分割し，両断端部を mini plate で固定した（C).

め，術中に和ける骨膜の剥離や術後に和ける部分的な皮 弁の壊死などが移植骨に対して感染を招来しやすい，乙 かしながら胸骨付大胸筋皮升の1例は，表層骨膜への血 行のみではあるが，海綿骨骨梁に富んでいるために，生 着への信頼性が高くて成功がもたらされた（写真6）. な颃，下顎骨の再建の症例では，術後に反応性炎症が強 く出現するために，顎間固定の施行は困難で，それに代 って強固な metal plate による固定が, きわめて重要で 

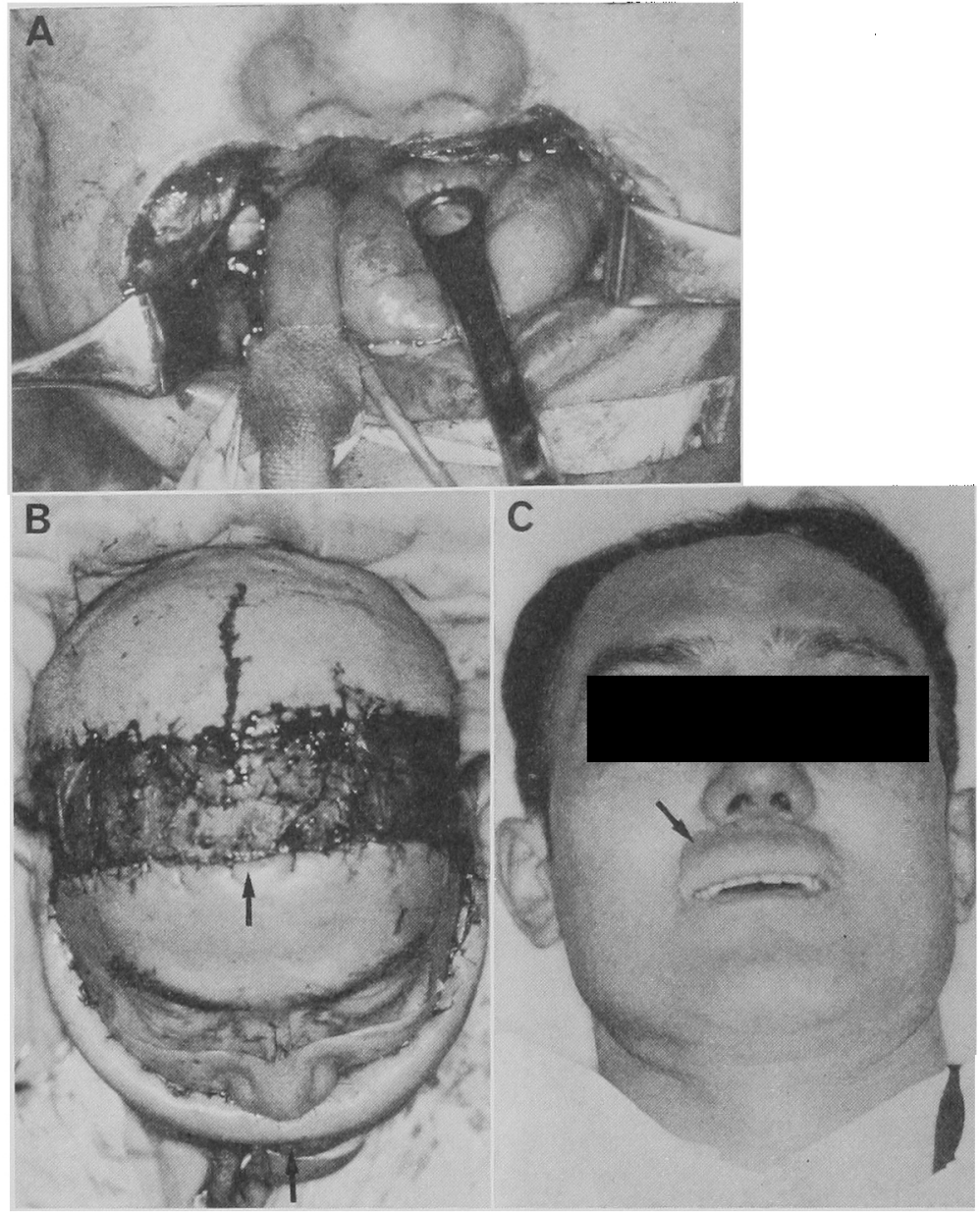

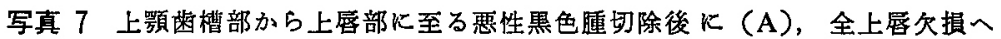
矢印の頭髪付前額皮弁を即時的に移動した（B）。广の後 1 か月ことに 皮弁を切離し，全上居を再建して義菌を装着した (C).

\section{あった17)}

\section{3. 前額皮弁}

成人，男珄の全上唇欠損に対する再建は，頭髧付前額 皮弁が適応となる。再建は皮升を即時的に上唇部へ移動 した後，1 か月ごとに左右側を切㜠し，番唇溝部に縫合 した． 2 例とも前額中央部の頭髮を利用して，上唇をカ モフラージュすることができたが，赤唇の形成までは行 い得なかった。機能的には，上唇の運動性は欠如した が，形態的には術後に義歯を装着することによって，審 美的回復が十分に可能であった（写真 7).

\section{4. 胸鎖乳突筋皮弁}

口底就よび下買の中等度の欠損の 2 例飞対して，頸部 郭清時に胸鎖乳突筇皮异を作製し，即時的に再建した。 すなわち，前方部の口底癌による切除創の再建に対して は, 全頸部郭㴔術時に下方の頸部仙島状皮我を作製し,
これを移動した．しかし血行不十分のため，この皮弁は

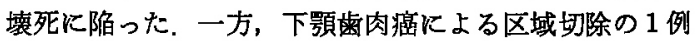
に対しては，顎骨の欠損部は A-O plate によって固定 し，粎槽部に対しては胸鎖乳突筋に広頸筋を付した頸部 島状皮弁を用いて再建を試みたところ，皮弁の生着がみ られた（写真 8)。

\section{5. 頸部島状皮弁}

舌・口底部の半側切除や，煩部扣よび下顎辺縁切除な どの中等度の久損の 5 例に対して，即時再建を行った （写真 9). 頸部島状皮弁は, 頸部郭清時に広頸筋を含め て皮弁を作製することができる簢便さはあるが，皮弁の 大きさには限界があった。

舌の半側切除の 3 例では, 舌根部之咽頭側壁部の縫合 時に過度の㔰張が加わった 2 例には部分的に皮并の壊死 がみられたが，いずれも表層部のみであった。 


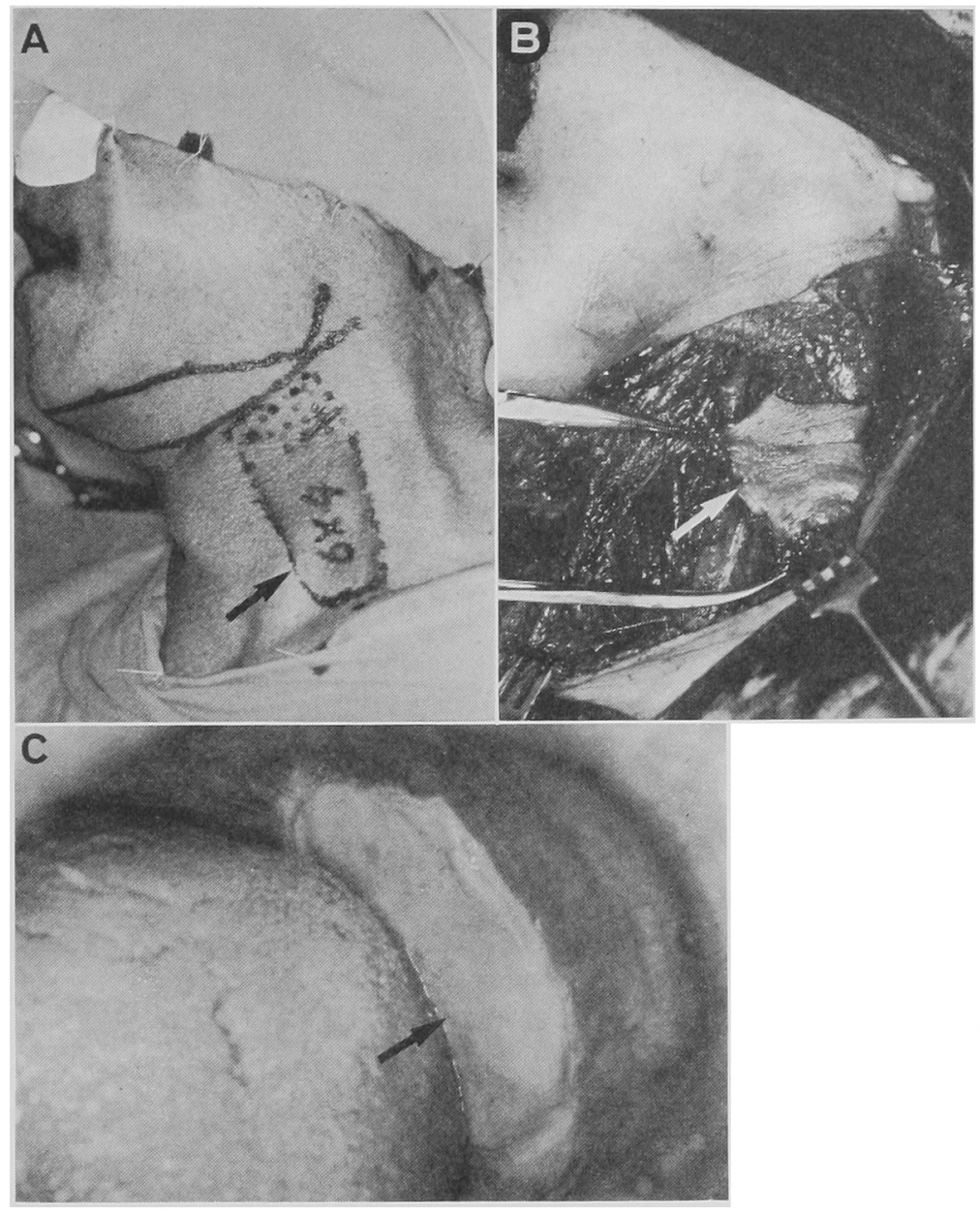

写真 8 下䫇歯肉癌による区域切除後の再建例てめる。広脴笳付胸鎖乳突筋皮弁 をデザイン（A）し，頸部郭清時に島状皮弁（B）を作製した。椺し た下顎骨は A-O plate で固定し，また歯槽部は皮弁で修復した（C）。

\section{6. 合併症（表 3)}

頸部島状皮并の部分的壊死は，5 例中 2 例にみられ， それは皮弁の表層部に発生した。 大胸筋皮弁では，14例 中 4 例の遠位端部に部分的な壊死がみられた，胸鎖乳突 筋皮茾では，島状皮弁部の全壊死が 2 例中 1 例に灭られ た. これは全頸部郭清を行うと，皮升への血行が不十分 になることが示唆されているものと思われる。

皮膚口腔瘦が35例中の 7 例にみられ，そのらち 3 例は 䫇骨の辺縁切除例に，また他の 4 例は区域切除後の顎骨 断端部にみられたが，いずれる自然に閉鎖した，骨付皮 升の感染は， 7 例中の 4 例にみられ，そのらち大胸筋皮 弁の 2 例は摘出を施行した。敗血症は口底癌の高度進展 の】例にみられた。 これは舌亜全摘, 下顎骨区域切除, 両側顓部郭清後に大胸筋皮弁で再建した症例で，術中の 出血量多多く，術後の14日目に死亡した。

\section{表 3 合併症（35皮弁）}

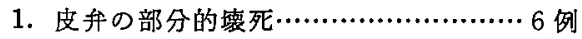

2. 皮弁の全壊死……........................ 1 例

3. 口腔皮膚嬷………......................... 7 例

4. 移植骨感染………………....... 7 例中 4 例

5. 敗血症………........................... 1 例

\section{7. 再建後の経過（表 4)}

悪性腫湟を切除した34例のらち，局所再発のみられた 3 例は, いずれも三次的治療として隀瘍の切除後に大胸 筋皮并，前額皮弁执よび D-P 皮并空用いての再建例で あった，再建部に括ける顎下リンパ節の転移は 3 例にみ られ，大胸筋皮弁が 2 例，D-P 皮弁が 1 例で，いずれむ 再建手術が転移巣の発見を困難にしていた，一方，肺転 


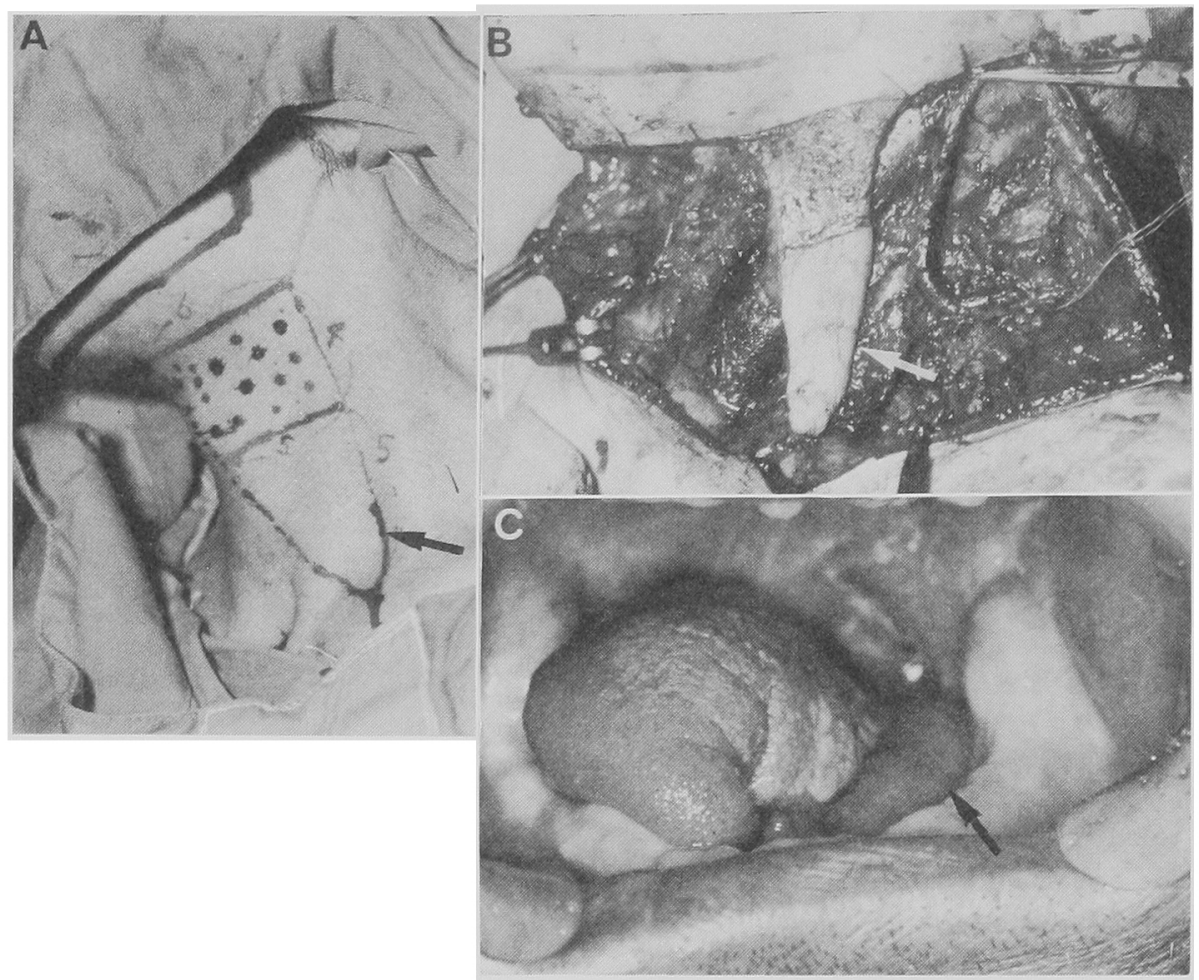

写真 9 舌癌に上る舌半側切除例である、頸部郭清時に広顆筋付頸部島状皮升をデザイン (A)，作製（B）し，舌・口底部を再建した（C)。

表 4 腫笏の経過 (34例)
1. 局所再発.....
3 例
2. 影部蔽移
3 例
3. 遠隔転移
2 例
4. 食道癌
1 例

表 5 生存率 $(1 \sim 5$ 年)

\begin{tabular}{|c|c|c|}
\hline 皮弁の種類 & 例 & 率 \\
\hline 1. D-P 皮弁……...... &.$\cdot 11$ & 81.8 \\
\hline 2. 大胸筋皮弁…... &. .14 & 57.1 \\
\hline 3. 前額皮弁…...... &.$\cdot 2$ & 100.0 \\
\hline 4. 眴鎖乳突筋皮弁 &.$\cdot 2$ & 100.0 \\
\hline 5. 頸部島状皮弁.. &. .5 & 100.0 \\
\hline 部 & 34 & 76.5 \\
\hline
\end{tabular}

䔟は2 例にみられ，これらは高度進展の血管肉腫と再発 腺癌であった。 また進展した口底癌を大胸筋皮弁で再建 した 1 例では， 1 年後に食道癌が発生した，

各種の皮弁による再建後，１～5 年を経過した生存率
（表 5）をみると，腫煌切除後に二次的に再建を施行し た D-P 皮升は， $81.1 \%$ と高い成結であった。これに対 して, 進展した脏瘍の鸟除後の大欠損部を即時的に再建 した大胸筋皮弁では， $57.1 \%$ と低い成績であった。一 方，前額皮弁と中等度欠損に対する胸鎖乳突筋皮并拈よ び頸部島状皮弁は，いずれも即時再趡ではあるが，100\% の成績であった。

\section{考}

察

進展した上顎癌や煩粘膜癌の切除後の煩部全層欠損の 再建には，前額皮升を使用したこともあったが，前額部 の政痕を後遗するので，最近では D-P 皮弁が多用され ている，D-P 皮弁は手術の侵襲は少ないが，皮弁の delay， 口腔側の裹打ち，あるいは pedicle の切離などに 長期間を要するなどの欠点がある．しかしながら皮升の 作製に創意工夫を加えると，さまざまな欠椇の再建が可 能になる長所がある゙2

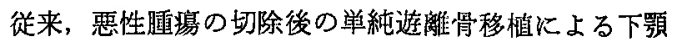
骨の再建の成績は，きわめて低いむのであった吕）それ に代って 近時は，血管付遊陮筋骨皮弁による再建が 報 皆10,23 25)され，注目されるよらになった。 しかし技術的 
な困難さがあり，いまだ肋骨付または胸骨付大胸筋皮办 による即時的再建が行われている，本法の骨への血行は 骨膜に依存しているので，骨採取時に骨膜を剝離しない よらに細心の注意が払われなければならない、単純遊離 骨移植に比べると，このような筋骨皮弁による下䫇骨再 建の成績は優れている。しかし合併症を伴うことが多 く，必ずしも信頼性の高いものとはいえない17)一方， 移植した腸骨付または胁骨付の D-P 皮弁も, 生着に安 全性はあるが，下顎部では移植骨の骨皮質に感染をきた しやすい これに対して, metal plateによる䫈骨の固 定は，二次的な下顎骨の再建を必要とするものの，この 際には移植骨の生着に安全性がある ${ }^{26)}$ しかし悪性腫瘍 の手術患者は，二次的再建手術を希望しない場合もあ り, 可能ならば即時的再建が望ましい.

舌可動部の半側程度の欠損は, 頸部島状皮弁を用いて も修復は可能である。しかし mass augmentation が得 られないので, 残存舌の形態と機能を補うためには, 術 後に口蓋補経物を装着する必要がある13) 舌亜全摘後の ような大欠損部の再建には，大胸筋皮弁が適応になる。 この際, $1 / 3$ 程度の残存舌でも, 機能は比較的良好であ るが, 舌尖部の切除例では, 会話, 䒚下にかなりの困難 性を伴っていた。

舌癌およびロ底癌などで, 腫瘳が下罘骨に近接してい た例では，下䫇の辺縁切除後に同部を大胸筋皮弁で修復 すると，下顎の形態は良好で義歯も装着できた ${ }^{6)}$ 全上 唇の欠損は女性では D-P 皮弁が適応となるが，男性で は頭髮付前額皮弁が最も優れている7 。本皮弁はひげを カモフラージュできるとともに，採取した弁の位置が頭 頂部に近くなるので, 般痕もあまり目立たない,8)

大胸筋皮弁, 胸鎖乳突筋皮弁, 頸部島状皮弁などで は，頸部郭清創を利用しての即時的再建が行われてい る.しかし悪性腫瘍の手術では, 腫瘍の切除に自信がも てないときは，再発を考虑しなければならないので，二 次的再建に委ねるべきであろう。これに対し十分に腫陽 を切除できた大欠損部は, 形態と機能の堮失および洀痕 拘篗を後遣することから，即時的再建を行らべきであ る。しかし一般的には, 術者の経験と好みによるところ が大きい，われわれの経験でも，高度進展症例に対する 大胸筋皮弁による再建後の生存率は, 予期した程の成績 ではなかった。これは遠隔転移のみでなく, 大量照射例 では，局所再発と頸部リンパ節郭清後の再発があり，と くに顎下部付近では再建後の転移巣の発見が遅れる欠点 があった. 一方, 二次的再建を行った D-P 皮弁の生存 成績は, 当然のことながら大胸筋皮并に比べて有意に侵 れていた。これは腫瘍の進展が比較的軽度で, かつ発症 部位が切除と再建を容易にしていたものと推察される。

\section{結 論}

1) 口腔・顎・顔而火損の再建は, 行種皮弁の長短, 欠損の大きさと部位, 腫場の進展度および切除時の腫掦 残存の可能性などを，総合的に判断した上で，適応を決 めることが重要である。

2）骨付大胸朌皮杂捄上び移植骨付 D-P 皮升による 下頭骨の再建は，骨への血行が必ずしも十分でないこと から, 今後は血管柄付遊離骨移植などによる安全な方法 を検討していく必要がある。

3) 再建後の生存成績は，大胸筋皮升に上る即時再建 例が，D-P 皮弁による二次的再建例に比べて劣るが，こ れは原発腫愓の部位と進展度に左右されるところが大き かったものと考えられる。

4 ）再建後の経過を検討すると, 腫瑄の局所再発や頸 部の転移は大量照射例に多く，かつ再建手術がこれらの 発見を遅らせていた。

\section{引用 文 献}

1) Bakamjian, V.Y.: A two stage method for Pharyngoesophageal reconstruction with a primary pectoral skin flap. Plast Reconstr Surg 56: 171-177 1975.

2) 鳥居修平, 長山勝, 他: Deltopectoral flap の作製法と臨床応用。 日外誌 25：1474-1481 1979.

3) Ariyan, S.: The pectoralis major myocutaneous flaps. A versatile flap for reconstruction in the head and neck. Plast Reconstr Surg 63: 73-81 1979.

4) Ariyan, S.: Further experience with the pectoralis major myocutaneous flap for the immediate repair of defects from excisions of head and neck cancers. Plast Reconstr Surg 64: 605-612 1979.

5) Beak, S.M., Lawson, W., et al.: An analysis of 133 pectoralis major myocutaneous flaps. Plast Reconstr Surg 61: 460-467 1982.

6）工藤啓吾，柘植信夫，他：大胸筋皮弁に上る口 腔痛切除後の即時再建. 日口外誌 29: 514-521 1983.

7) Loré, J.M.: An atlas of head and neck surgery I. 2nd Ed, Saunders, Philadelphia, 1973, p 316-317.

8) Kudo, K., Yokota, M., et al.: Immediate reconstruction using a scalpforehead flap for the entire upper lip defect with the application of lyophilized porcine skin surgical wounds. A case report of a malignant melanoma in the upper lip and oral mucosa. J max-fac surg 11: 275-278 1983. 
9) Ariyan, S.: One-stage reconstruction for defects of the mouth using a sternomastoid myocutaneous flap. Plast Reconstr Surg 63: 618-625 1979.

10) Ariyan, S.: Pectoralis major, sternomastoid and other musculocutaneous flaps for head and neck reconstruction. Clin Plast Surg 7: 89-109 1980.

11) Farr, H.W., Jean-Gilles, B., et al.: Cervical island skin flap repair of oral and pharyngeal defects in the composite operation for cancer. Am J Surg 118: 759-763 1969.

12) Colman, J.J., Jwrkiewicz, M.J., et al.: The platisma musculocutaneous flap: experience with 24 cases. Plast Reconstr Surg 72: 3153211983.

13）工藤啓吾，柘植信夫，他 : Cervical island skin flap 口腔癌切除後の 即時再建. 日口外誌 31 : 661-666 1985.

14) Cuono, C.B. and Ariyan, S.: Immediate reconstruction of a composite mandibular defect with a regional osteomyocutaneous flap. Plast Reconstr Surg 65: 477-483 1980.

15) Green, M.F., Gibson, J.R., et al.: A onestage correction of mandibular defects using a split sternum pectolaris major osteomusculocutaneous transfer. Br J Plast Surg 34: 11161981.

16) Little, J.W., McCulloch, D.T., et al.: The pectoral composite flap in one-stage reconstruction of the irradiated mandible. Plast Reconstr Surg 71: 326-355 1983.

17) Kudo, K., Miyasawa, M., et al.: Immediate repair of mandibular defects following surgery for carcinoma of the lower alveolus and gingiva using a pectralis major osteomyocutaneous flaps. J max-fac Surg 13: 116-120 1985.

18) Lam, K.H., Wei, W.I., et al.: The pectoralis major costomyocutaneous flap for mandibular reconstruction. Plast Reconstr Surg 73: 9049101984.

19）河合 幹, 加藤正樹，他：简状皮弁中に腸骨片 を遊離移植した皮弁と骨を一体として下顎の修 復を行った一例. 日外誌 24：635-639 1978.

20) Conley, J.: Regional flaps of the head and neck. Thieme, Stuttgart, 1976, p 203-205.

21）小宮善昭, 北薗久大, 他：高線量術前炤射後に 即時再建を行った進展料肉瘦の 2 例. 日口外誌 26: 202-208 1980.

22) Kudo, K. and Fujioka, Y.: Review of bone grafting for reconstruction of discontinuity defects of the mandible. J Oral Surg 36: 791-793 1978.

23) Bitter, K.: Bone transplants from the iliac to the maxillo-facial region by the microsurgical technique. J maxillo-facial Surg 8: 210-216 1980.

24）工藤啓吾, Brown, W.C., 他 : 複合肋骨移植時 の血流に関する研究。日口外誌 $27: 846-850$ 1981.

25) Bitter, K., Schlesinger, S., et al.: The iliac bone or osteocutaneous transplant pedicled to the deep circumflex iliac artery. II Clinical application. J max-fac Surgery 11: 241-247 1983.

26) Krüger, E.: Reconstruction of bone and soft tissue in extensive facial defects. J Oral Maxillofac Surg 40: 714-720 1982. 